\title{
Preparation of PbS Quantum Dot Materials by the Sol-Gel Process
}

\author{
Toshimi TAKADA, Tetsuji YANO, Atsuo YASUMORI and Masayuki YAMANE \\ Department of Inorganic Materials, Tokyo Institute of Technology, 2-12-1, Ookayama, Meguro-ku, Tokyo 152 \\ ゾル-ゲル法による PbS 量子ドットの作製 \\ 高田としみ・矢野哲司・安盛敦雄・山根正之 \\ 東京工業大学無機材料工学科, 152 東京都目黒区大岡山 2-12-1
}

[Received July 16, 1992; Accepted September 22, 1992]

\begin{abstract}
Quantum dot materials based on PbS-doped sodium borosilicate glasses were prepared by the sol-gel process using silicon methoxide(TMOS), boron ethoxide, sodium and lead acetates as starting materials. The chemical state of $\mathrm{Pb}$ species in the glasses fully densified at $590^{\circ} \mathrm{C}$ was identified to be $\mathrm{PbS}$ by $\mathrm{X}$-ray photoelectron spectroscopy and electron diffraction. The amount of $\mathrm{PbS}$ crystallites in the glasses was 4-13 wt $\%$ of mother glasses. The size of the crystallites was 5-15 $\mathrm{nm}$ in diameter. The absorption edge of the glasses was near $2500 \mathrm{~nm}$, which was slightly shifted to higher energy from $3200 \mathrm{~nm}$ for the bulk $\mathrm{PbS}$ crystal.
\end{abstract}

Key-words : PbS, Quantum dot, Sol-gel process, Soda borosilicate glass

\section{Introduction}

Nano-sized semiconductor and metal particles such as CdS, CdSe, CdTe, PbS, Au, Ag, etc. dispersed in a dielectric medium has recently been receiving a great deal of attention as quantum dot materials which exhibit a large resonant non-linear susceptibility with picosecond-order response time. ${ }^{1-4)}$ The sol-gel process is advantageous over conventional melt-quenching technique in preparing these quantum dot materials when semiconductor particles are easily oxidized or decomposed at high temperatures.

This advantage becomes significant when gel is fully densified into a pore-free glass that is essential for practical device application. Most reports on the preparation of quantum dot materials by the sol-gel process, however, deal with silica gels which can not be densified at low temperatures where the decomposition or oxidation of the semiconductor materials does not occur. 5)-7)

Recently, we succeeded in preparing optically transparent, fully densified glasses of $\mathrm{Na}_{2} \mathrm{O}-\mathrm{B}_{2} \mathrm{O}_{3}-$ $\mathrm{SiO}_{2}$ system containing up to $10 \mathrm{wt} \% \mathrm{CdS}$ crystallites of $5-10 \mathrm{~nm}$ in diameter by the sol-gel process, using TMOS, $\mathrm{B}(\mathrm{OEt})_{3}$, aqueous $\mathrm{NaOAc} / \mathrm{Cd}(\mathrm{OAc})_{2}$ solution as starting materials. ${ }^{8)} 10 \mathrm{wt} \% \mathrm{CdS}$-doped gel-derived glasses showed a $\chi^{(3)}$ of $1 \times 10^{-6}$ esu under near resonant conditions, i.e., in the vicinity of $460 \mathrm{~nm}$.

This process of preparing the CdS-doped glasses can be applied, in principle, to any other sulfide semiconductor dispersed systems provided that the sulfide is stable up to $600^{\circ} \mathrm{C}$.

The energy gap of bulk $\mathrm{PbS}$ crystal is reported to be $0.286 \mathrm{eV}$ at $4 \mathrm{~K}$ and the absorption edge of $\mathrm{PbS}$ shifts to higher energy from $3200 \mathrm{~nm}$ for the bulk crystal up to $530 \mathrm{~nm}$ for the particle smaller than $1.3 \mathrm{~nm} .{ }^{9)}$ Thus the quantum dot materials with nanosized $\mathrm{PbS}$ having resonant conditions near the wavelength for optical communication should be obtainable by controlling the particle size. The fabrication of such materials with high nonlinearity is of practical importance for the development of optical switching device for communication.

Since $\mathrm{PbS}$ decomposes at a temperature above $600^{\circ} \mathrm{C}$ in ambient laboratory atmosphere, our process based on soda-boro-silicate system is particularly advantageous over other methods in fabricating full dense quantum dot materials of $\mathrm{PbS}$-dispersed system.

In this paper, we report the preparation of $\mathrm{PbS}$-dispersed full dense glasses by the sol-gel process developed for the fabrication of CdS-doped quantum dot materials.

\section{Experimental}

\subsection{Preparation of glasses}

The composition of the matrix glass and the procedure for the gel preparation and subsequent treatments were similar to those used in the fabrication of CdS-doped glasses ${ }^{8)}$ except that $\mathrm{Pb}(\mathrm{OAc})_{2} \cdot 3 \mathrm{H}_{2} \mathrm{O}$ was used for $\mathrm{Cd}(\mathrm{OAc})_{2} \cdot \mathrm{H}_{2} \mathrm{O}$. That is, the process consisted of: preparation of $\mathrm{Pb}(\mathrm{OAc})_{2}$ doped wet gel, precipitation of $\mathrm{Pb}(\mathrm{OAc})_{2}$ microcrystallites in the gel, conversion of $\mathrm{Pb}(\mathrm{OAc})_{2}$ to $\mathrm{PbO}$ by heating the gel in air, conversion of $\mathrm{PbO}$ to $\mathrm{PbS}$ by exposing the gel to $\mathrm{H}_{2} \mathrm{~S}$, and densification of $\mathrm{PbS}$-doped gel.

Precursor solutions with the composition of $6.25 \mathrm{Na}_{2} \mathrm{O}-18.1 \mathrm{~B}_{2} \mathrm{O}_{3}-80 \mathrm{SiO}_{2}$ (in $\left.\mathrm{mol}\right)+x \mathrm{PbO}(x=5$, $10,15 \mathrm{wt} \%$ ), were prepared from TMOS, B (OEt $)_{3}$, and aqueous $\mathrm{NaOAc} / \mathrm{Pb}(\mathrm{OAc})_{2}$ solution. Taken consideration was the loss of $\mathrm{Na}_{2} \mathrm{O}$ and $\mathrm{B}_{2} \mathrm{O}_{3}$ due to extraction when acetone replaces the liquid inside the wet gel for precipitating $\mathrm{Pb}(\mathrm{OAc})_{2}$ microcrystallites. ${ }^{10)}$

First, $2.0 \mathrm{~g}$ of TMOS was hydrolyzed with $0.489 \mathrm{~g}$ 
of aqueous hydrochloric acid of $\mathrm{pH}=2$ (molar ratio of TMOS: $\mathrm{H}_{2} \mathrm{O}=1: 2$ ) for $1 \mathrm{~h}$ at $20^{\circ} \mathrm{C}$ by ultrasonic irradiation at $25 \mathrm{kHz}$. Next, $0.897 \mathrm{~g}$ of $\mathrm{B}(\mathrm{OEt})_{3}$ was added to this silicate solution and mixed for $1 \mathrm{~h}$ at $20^{\circ} \mathrm{C}$ for another hour with ultrasonic irradiation. Then, the aqueous solution of freshly dissolved $0.174 \mathrm{~g}$ of $\mathrm{NaOAc}$ and $0.089 \mathrm{~g}$ of $\mathrm{Pb}(\mathrm{OAc})_{2} \cdot 3 \mathrm{H}_{2} \mathrm{O}$ in $0.819 \mathrm{~g}$ distilled water $(x=5 \mathrm{wt} \%$, Sample-A), or $0.174 \mathrm{~g}$ of $\mathrm{NaOAc}$ and $0.178 \mathrm{~g}$ of $\mathrm{Pb}(\mathrm{OAc})_{2} \cdot 3 \mathrm{H}_{2} \mathrm{O}$ in $0.941 \mathrm{~g}$ distilled water $(x=10 \mathrm{wt} \%$, Sample-B), or $0.174 \mathrm{~g}$ of $\mathrm{NaOAc}$ and $0.267 \mathrm{~g}$ of $\mathrm{Pb}(\mathrm{OAc})_{2} \cdot 3 \mathrm{H}_{2} \mathrm{O}$ in $1.237 \mathrm{~g}$ distilled water ( $x=15 \mathrm{wt} \%$, Sample-C), was added to the mixture and mixed by ultrasonic agitation for $10-20 \mathrm{~min}$ at $0^{\circ} \mathrm{C}$. The precursor solution thus obtained was poured into a tightly sealed polypropylene vial of about $33 \mathrm{~mm}$ inside diameter. The solution was gelled and aged at room temperature for $6 h$.

The aged wet gel was then placed in $10 \mathrm{ml}$ of 10 vol\% iso- $\mathrm{PrOH} /$ acetone solution at room temperature for 3 days, in order to replace the liquid in the micropores of the gel with the solution and to precipitate $\mathrm{Pb}(\mathrm{OAc})_{2}$ microcrystallites on the micropore walls. The gel thus treated was dried at $60^{\circ} \mathrm{C}$ for two weeks.

The monolithic porous dried gels of about $23 \mathrm{~mm}$ in diameter and $1.7 \mathrm{~mm}$ in thickness were subjected to heat treatment at $400^{\circ} \mathrm{C}$ for $12 \mathrm{~h}$ in a silica tube with flowing oxygen gas, in order to decompose and convert $\mathrm{Pb}(\mathrm{OAc})_{2}$ into $\mathrm{PbO}$. The $\mathrm{PbO}$ containing gels after being cooled to room temperature were exposed to dry $\mathrm{H}_{2} \mathrm{~S}$ gas to convert $\mathrm{PbO}$ to $\mathrm{PbS}$ at $100^{\circ} \mathrm{C}$ for $6 \mathrm{~h}$ in a silica tube previously evacuated of $\mathrm{N}_{2}$ by a rotary pump. The gels were then heated to $590^{\circ} \mathrm{C}$ in flowing helium gas for $7 \mathrm{~h}$ for densification into porefree glasses.

2.2 Characterization of glasses and measurement of absorption spectra

The $\mathrm{Pb}$ contents in the final glass was determined by the measurement with a SEIKO EG \& G Type SED 8600 energy dispersive X-ray analyzer (EDX) and the chemical state of $\mathrm{Pb}$ species was investigated by X-ray photo spectroscopy (XPS) using Perkin Elmer ESCA-5500MT spectrometer. The spectra of $\mathrm{Pb}_{4 \mathrm{f}}$ and $\mathrm{S}_{2 \mathrm{~s}}$ electrons were measured over the ranges $125-150 \mathrm{eV}$ and $217-237 \mathrm{eV}$ using the monochromatic $\mathrm{Al} \mathrm{K} \alpha$ radiation at $300 \mathrm{~W}$.

Electron micrographs and the electron diffraction pattern of the $\mathrm{PbS}$ particles in the densified glasses were obtained by using the JOEL TEM-100CX transmission electron microscope at $100 \mathrm{kV}$. Samples were fragmented and dispersed in carbon tetrachloride $\left(\mathrm{CCl}_{4}\right)$. The solution was then dropped onto a holey carbon film supported by a copper grid.

The measurement of absorption spectra was carried out on the platelet samples of about $100 \mu \mathrm{m}$ in thickness over the wavelength from $800 \mathrm{~nm}$ to 2500 $\mathrm{nm}$ with Near-IR Spectrometer JASCO UVIDEC590 using air as the reference.
3. Results and discussion

3.1 Composition and crystallite development of $\mathrm{Pb}$ species

The $\mathrm{Pb}$ contents in the samples determined by EDX were $4.3,8.5$ and $13 \mathrm{wt} \%$ in terms of $\mathrm{PbS} /$ mother glass, respectively. These values are slightly lower than those in precursor solutions. This reduction in $\mathrm{Pb}$ content is due to the extraction loss by syneresis of the liquid from wet gel. ${ }^{10)}$

Figure 1 shows the XPS spectra of $\mathrm{Pb}_{4 \mathrm{f}}$ and $\mathrm{S}_{2 \mathrm{~s}}$ electrons on Sample-C containing $13 \%$ of $\mathrm{PbS}$. Both of the peaks at $137.5 \mathrm{eV}$ for $\mathrm{Pb}_{4 \mathrm{f}}$ and at $225.1 \mathrm{eV}$ for $\mathrm{S}_{2 \mathrm{~s}}$ are characteristic of $\mathrm{PbS}$ and there is no other peak which is assigned to the $\mathrm{Pb}$ compound in other state. ${ }^{11)}$ The information on the lead which had been incorporated in glass structure as modifier ions was not obtained. However, its amount, if any, is considered to be small from the processing conditions.

The electron diffraction pattern of Sample-C having $\mathrm{PbS}$ content of $13 \mathrm{wt} \%$ is shown in Fig. 2. The spots in the figure were identified to be the reflection from the (111), (200), (220), (311), (222), (420), (422) and (600) planes of PbS. The very distinct spots in the diffraction pattern suggest that each particle is a single crystal.

The TEM micrograph of Sample-C is shown in Fig. 3. PbS appears as dark particles with diameters ranging from 5 to $15 \mathrm{~nm}$. Both average size and the range of size distribution are very large compared

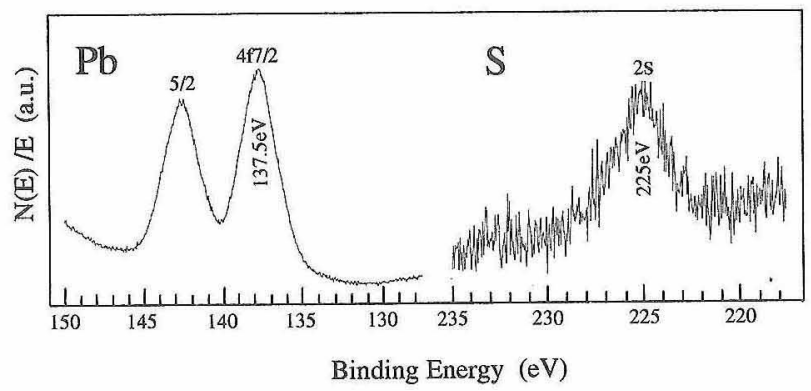

Fig. 1. $\mathrm{Pb}_{4 \mathrm{f}}$ and $\mathrm{S}_{2 \mathrm{~s}}$ spectra for lead compound in Sample-C.

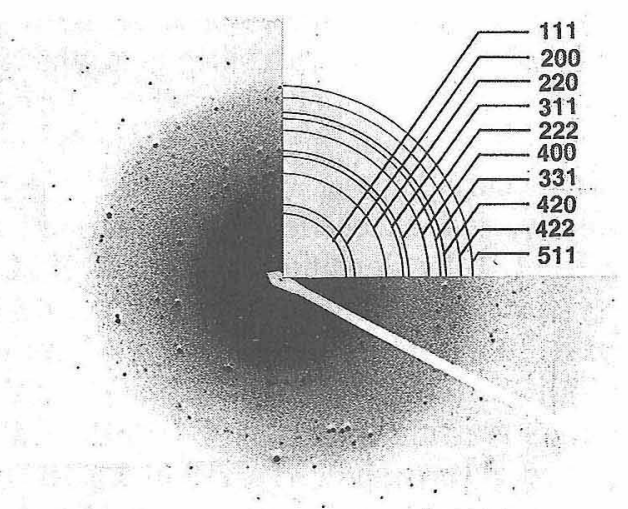

Fig. 2. Electron diffraction pattern of lead compound in Sample-C. 


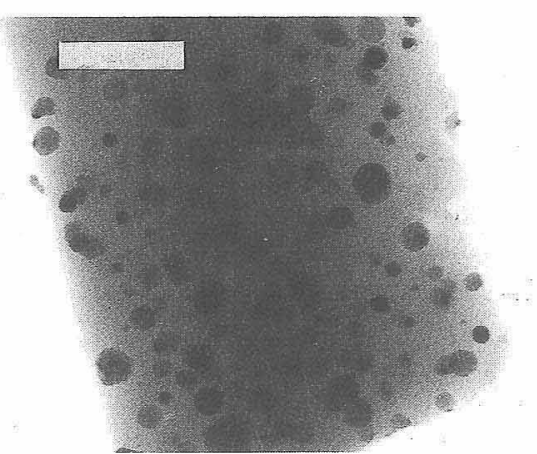

Fig. 3. TEM micrograph of Sample-C (white bar $=100 \mathrm{~nm}$ ).

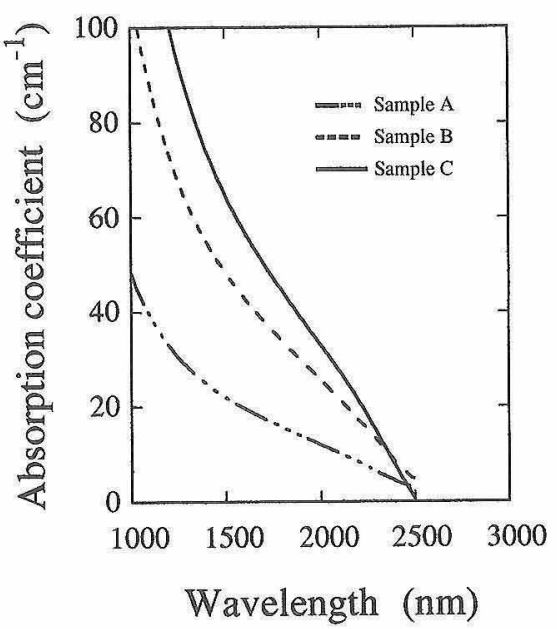

Fig. 4. Absorption spectra of glasses with $\mathrm{PbS}$ content of; A: $4.3 \mathrm{wt} \%, \mathrm{~B}: 8.5 \mathrm{wt} \%, \mathrm{C:}: 13 \mathrm{wt} \%$.

with those of CdS microcrystallites i.e., $6 \pm 2 \mathrm{~nm}$, prepared by the similar procedure ${ }^{8}$ )

3.2 Absorption spectra

The absorption spectra of Samples A-C are shown in Fig. 4. There is not so distinct difference of the absorption edge among three samples due to broad particle size distributions, although the edge shifted slightly to higher energy from $3200 \mathrm{~nm}$ for the bulk $\mathrm{PbS}$ crystal. There is an indication of the shoulder in the vicinity of $2200 \mathrm{~nm}$ in the spectrum of Sample-C containing $13 \mathrm{wt} \%$ of $\mathrm{PbS}$. This is probably attributed to the resonant absorption typical of quantum dot materials.

The wavelength of $2200 \mathrm{~nm}$, where a high nonlinear susceptibility is expected, is too long to be immediately applied to the optical communication system. The elaboration of the processing conditions to obtain the $\mathrm{PbS}$ microcrystallites of smaller size and narrower size distribution is the next step of the study to prepare the materials fit to the application.

\section{References}

1) R. K. Jain and R. C. Lind, J. Opt. Soc. Am., 73, 647-53 (1983).

2) N. F. Borrelli, D. W. Hall, H. J. Holland and D. W. Smith, J. Appl. Phys., 61 ,5399-409 (1987).

3) P. Roussignol, D. Ricard, J. Lukasik and C. Flytzanis, $J$. Opt. Soc. Am., B4, 5-13 (1987).

4) M. Kull and J. L. Coutaz, J. Opt. Soc. Am., B7, 1463-72 (1990).

5) M. Nogami, K. Nagasaka and K. Kotani, J. Non-Cryst. Solids, 126, 87-92 (1990).

6) N. Tohge, M. Asuka and T. Minami, SPIE Proc., 1328 , 125-32 (1990).

7) R. Reisfeld, H. Minti and M. Eyal, SPIE Proc., 1513, 360 (1991).

8) T. Takada, T. Yano, A. Yasumori, M. Yamane and J. D. Mackenzie, J. Non-Cryst. Solids, in press.

9) Y. Wang, A. Suna, W. Mahler and R. Kasowski, J. Chem Phys., 87, 7315-22 (1987).

10) T. Takada, T. Yano, A. Yasumori and M. Yamane, J. NonCryst. Solids, 134, 32-38 (1991).

11) D. S. Zingg and D. M. Hercules, J. Phys. Chem., 82, 199295 (1978). 